Archived version from NCDOCKS Institutional Repository http://libres.uncg.edu/ir/asu/

McDaniel, T. M. \& Groothuis, P. A. (2012). Retail competition in electricity supply Survey results in North Carolina. Energy Policy, 48, 315-321.

\title{
Retail competition in electricity supply-Survey results in North Carolina
}

\author{
Tanga M. McDaniel \& Peter A. Groothuis
}

\begin{abstract}
Residential retail competition in electricity supply was introduced in many countries and some US states as part of electricity industry deregulation. Following problems in the electricity market in California in 2000/2001 many US states, including North Carolina, suspended their deregulation agenda. Recent technological advances have made competition more viable, so we ask if NC should reconsider deregulation and retail competition. The welfare benefits will depend on consumers' willingness to switch suppliers and the potential for value added innovations. In electricity and industries such as pay-tv and telecommunications consumers are 'sticky', remaining with their current supplier even though rivals offer savings. Moreover, some analysts question the likelihood of significant welfare improvements from retail competition. We survey residents in two NC counties focusing on: (i) households' knowledge of and interest in retail competition, (ii) factors that would encourage them to switch suppliers and (iii) the required savings to encourage switching. About $50-65 \%$ of respondents would favor retail competition in NC. Demographic variables and experience switching in other industries affect opinions and the savings required to incent switching. We conclude the estimated rate reduction to encourage competitive switching will be hard to achieve in $\mathrm{NC}$ as long as rates remain below the national average.
\end{abstract}

\section{Key words}

Electricity supply; Retail competition; Switching 


\section{Introduction}

Competition in retail electricity supply has been introduced in many countries around the world and is a mandate for European Union member states. In the US, 15 states plus the District of Columbia have introduced retail competition but most states have a nonactive deregulation agenda for the electricity industry. Federal regulatory Acts and Orders helped to lay the foundation for wholesale and retail competition in the US. Three notable examples were the 1992 Energy Policy Act and Federal Energy Regulatory Commission (FERC) Orders 888 and 889 of 1996. The 1992 Act empowered "FERC to order vertically integrated electric utilities to deliver competitive generated power over their transmission lines to wholesale customers, a process known as wholesale wheeling (Sidak and Spulber, 1998)." The 1996 Orders made the 1992 Energy Act more comprehensive by requiring transmission operators to allow open access to their networks on the basis of non-discriminatory tariffs. Order 888 also contained a concession from regulators to the incumbent utilities allowing them to recover stranded investments and recoup costs made before deregulation that may not have been cost effective under competition.

Retail electricity competition potentially includes sales to all electricity customers: industrial, commercial, small business and residential. Markets for smaller customers, particularly residential, present significant challenges to the competitive market model. In this paper we ask if one US state, North Carolina (NC), should reconsider retail competition in electricity supply. Our focus is on the residential market or residential retail competition (hereafter, $\mathrm{RRC}$ ). NC is not unlike adjacent states in size and the generation fuel mix, but we do not attempt to extrapolate our results beyond NC.

Using survey data, we estimate factors affecting the desirability of RRC to residential consumers in Western NC. We discuss three basic questions. First, what is the current level of familiarity with retail competition and what characteristics result in individuals being more favorable toward it? Second, what supply options (not currently received) would entice households to consider an alternative supplier? Third, holding supply characteristics constant, how much would the monthly electricity bill have to decline to encourage switching?

Research on the feasibility of retail competition in many US states has tapered off since the breakdown of the competitive market in California in 2001. Fig. $1 \mathrm{a}$ and $\mathrm{b}$ shows the status of restructuring efforts in the US in 2001 and in 2010, respectively. In the figure for 2010 we have superimposed the average residential price for electricity in 1998, 2 years after FERC Orders 888 and 889 . We chose to illustrate prices in 1998 because, although the restructuring debate and requisite (federal) legislation occurred earlier, restructuring and/or competition itself was beginning in some markets at that time (e.g., California and Massachusetts). Average prices go a long way in explaining restructuring efforts across states. In most currently "active states" the average retail price was above the national average in 1998; the two exceptions were Texas and Oregon. In contrast, all the "not active" states excluding lowa, Alaska and Hawaii had rates below the national average. The "suspended" states had rates roughly in line with the national average apart from California, one of the earliest states to restructure. Overall, the 
average price in active states was $10.32 \mathrm{c} / \mathrm{kWh}$ while in suspended and non-active states it was $8.09 \$$ and $6.32 \$$, respectively (excluding Alaska and Hawaii where rates were well above the national average).
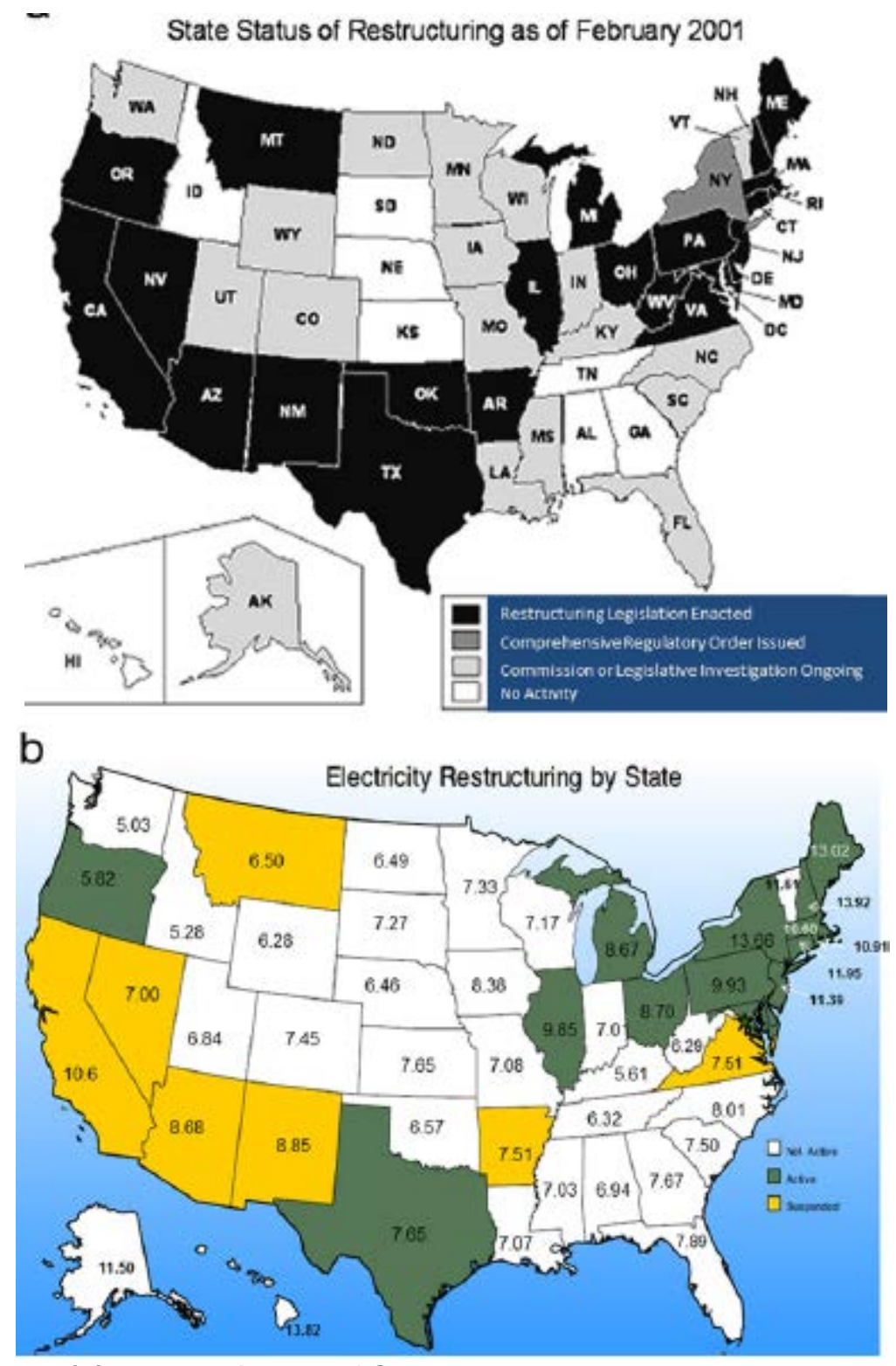

Fig. 1. (a) Source EIA. (b) Restructing as of September 2010: EIA.

http://www.eia.doe.gov/cneaf/electricity/page/restructuring/restructure elect.html. Real residential prices (\$/kWh), 1998. US average residential price by State by Provider (EIA-861).

In April 2000 a commission on the Future of Electric Service recommended to the NC state legislator that deregulation take place by January 2005 with $50 \%$ of customers being given supply choice at that time and the remainder a year later. By January 2001 these plans were postponed..$^{3}$ Comparing the maps in Fig. $1 \mathrm{a}$ and $\mathrm{b}$ it is clear that many states backed off on their restructuring plans following events in California. 
Early discussions and academic pursuits about electricity industry restructuring focused on creating and improving markets for power generation. This, in many cases, involved breaking up integrated companies into transmission, generation, and retail functions. The natural monopoly transmission segments of the market were separated from the potentially competitive generation and retail functions. In some markets, such as Great Britain, and some regions such as Pennsylvania-New Jersey-Maryland (PJM) this process moved forward relatively quickly. In the England and Wales market (which has since been expanded to include Scotland) the restructuring process began in the late 1980 s and early 1990 s and the residential market was opened to competition as early as 1998. The US market by contrast is more complex and segmented, and many policies are determined at the state level. Not surprisingly, the process has been slower in the US.

Today, restructuring and energy efficiency goals are very focused on the demand side of the market. There is an expectation that demand side changes will lead to more innovations and value added than continued emphasis on cost cutting at the wholesale level:

"Arguably most of the efficiency gains from restructuring will come from the demand side... Unfortunately, nearly all markets have paid too little attention to the demand side, and many markets began by effectively killing retail competition. This is unfortunate, since the much needed innovation on demand management systems and contracts is likely to come from retail competition." (Cramton, 2003, p. 6).

Joskow (2000) discusses various ways retail competition could provide value added. For example:

"...the primary social value of increasing [the] role of [electricity service providers] is to provide enhanced customer services which provide value added to consumers over and above what consumers realize by purchasing at wholesale through the [electric distribution company]. These services include enhanced metering and control technologies, price and consumption hedge contracts, total energy management services, bundling of a gas, electric, telephone service..." (Joskow, 2000, p. 5)

Defeuilley, 2009a and Defeuilley, 2009b suggests RRC has (to date) failed to deliver on some expected benefits, such as innovation. He states that new entrants have not been able to gain a lasting competitive advantage partly because new tools such as 'web based auditing" and "energy management software" are easily reproducible (p. 382). Moreover, he cites the existence of two consumer markets (active and inactive) and the differences in prices for those consumer groups as evidence of consumer inertia. Inertia persists for various reasons including the (perceived or real) complexity of comparing offers and switching suppliers.

The use of time varying prices promotes demand side management and would add value in the industry if demand elasticity increased. Indeed there is evidence from pilot studies that time varied electricity prices such as 'time of use' and 'critical peak pricing' 
can substantially reduce peak demand, particularly when consumers have access to enabling technologies that allow them to automate appliances (e.g., Faruqui and Sergici, 2010). However, this need not be a result of competition. Nakajima and Hamori (2010) do not find significant differences in the price elasticity of demand between regulated and deregulated states. Using panel data for cross sections of the US including (i) all states (plus DC), (ii) all regulated states and (iii) all deregulated states, they suggest, "It can be said... retail electricity market deregulation has not made ordinary electricity consumers more sensitive to electricity rates, and that retail deregulation policies are not the cause of price elasticity differences between deregulated and non-deregulated states" (p. 2475).

There remain important downsides and uncertainties associated with RRC. The anticipated costs and potential for abuse are greater for residential customers relative to industrial and commercial customers, and devising default services for customers unlikely to switch suppliers (while maintaining a margin for competitive entry) is a challenge. Moreover, for competition to benefit consumers and for them to embrace the possibilities, it must be easy to compare prices, monitor energy use, switch suppliers and switch again if problems arise. States are taking advantage of the internet to educate consumers and make price comparisons simpler. For example, The Texas Electric Choice, and Pennsylvania's PA Power Switch websites help consumers compare prices and choose new suppliers. ${ }^{5}$ Software is also available to help consumers monitor their use. Google PowerMeter offers customers fitted with a smart meter the ability to see how much power their home is using. A local power company, Blue Ridge Electric, has a webpage explaining to its smart meter customers how to install and use this Google software. ${ }^{6}$ Consumers without consistent internet access and some older residential customers would be disadvantaged, however, if the Internet became the primary source of information dissemination. This disadvantage could be minimized through the use of aggregated communities of individuals, some of whom will be better informed than others.

The remainder of the paper is organized as follows: Section 2 discusses the survey design, the counties surveyed and our results. In Section 3 we discuss our results in light of evidence from the US states that have deregulated, and in Section 4 we offer our conclusions.

\section{Survey and data analysis}

Two North Carolina counties were chosen for the survey. Watauga County is located in the mountains in the northwest part of the state. The population is approximately 46,000 and peak energy use occurs in the winter. The town of Boone and Appalachian State University are in Watauga County. Forsyth County is more urban and warmer though still located in the northwest portion of the state. Forsyth has a population of approximately 360,000; Winston Salem is the largest city and Wake Forest and Winston Salem University both are in Forsyth County.

The mail survey was conducted in October and November 2009. The first mailing consisted of 2100 households, half in Watauga County and half in Forsythe County, 
North Carolina. Both were random samples of all county residences purchased from Survey Sampling International. Approximately $10 \%$ of the surveys were undelivered, leaving us with 891 delivered in Watauga and 991 in Forsythe. A follow-up postcard was sent to all households approximately 1 week after the initial mailing. Excluding bad addresses, a second mailing of the full survey was sent to all non-responders 3 weeks later. In total we received 372 responses from Watauga households ( $42 \%$ of delivered surveys) and 357 responses from Forsyth households (36\% of delivered surveys). Table 1 shows the demographic characteristics of our sample.

Table 1. Demographic data.

\begin{tabular}{lll} 
& Watauga & Forsythe \\
\hline Average income & 62,879 & 73,197 \\
Age $^{2}$ & 61 & 61 \\
Male (\%) & 59 & 63 \\
\% of sample with some undergraduate education & 47 & 59 \\
\% of sample with some graduate education & 29 & 22 \\
\% of responders who are responsible for paying the & 86 & 85 \\
electricity bill & & \\
\hline & \\
a The age data are highly symmetric with a median, mean and mode around \\
60. Given the fact that this was a mail survey about energy efficiency and retail \\
competition, the high average is not too surprising.
\end{tabular}

In general, we find that fewer than half the sample respondents in both counties are currently familiar with retail competition but more than half would favor it. Similarly, approximately three-quarters consider it important to be able to choose their electricity provider. We also asked responders about their experience switching suppliers in other industries. Approximately $30 \%$ of the overall sample had switched either their telephone or television provider in the past 3 years. This experience might affect how comfortable they are with the process of changing providers and may also affect their attitude toward competition in utility markets.

In Table 2, we focuses on what attributes of service would entice responders to switch to an alternative provider, assuming all other aspects of their service remained the same.

Table 2. Switching preferences.

\begin{tabular}{lll}
$\begin{array}{l}\text { \% Customers who would (very or somewhat likely) } \\
\text { switch if offered: }\end{array}$ & Watauga Forsythe \\
& & \\
\hline Smart/hourly meter (no fee) & 65 & 57 \\
Incentives to weatherize & 62 & 62 \\
Green energy options & 61 & 63 \\
Green options but \$5/month bill increase & 30 & 36
\end{tabular}

\footnotetext{
${ }^{2}$ For many respondents this question was a missing value. We recoded the variable as 0 if they responded 'not likely' or 'don't know' to the previous question which asked how likely they would be to switch if another company offered more green energy options (such as purchasing more power from renewable sources like solar and wind).
}

We find that access to smart matters, incentives to weatherize and a free green energy option would all encourage a majority of respondent to switch providers. Green energy 
options with a fee increase would only encourage about a third of respondents to change providers. The data in Table 2 underestimate the actual percentages because subjects who responded that their provider already offers green options or incentives to weatherize are not included (approximately $19 \%$ of the overall sample). We did not include improved reliability as a reason to switch since current providers continue to maintain the distribution lines under most competition models in the US.

Finally, we present the results from the regression analysis. Our dependent variable is 'savings', the amount a household stated their electricity bill would have to fall (all else equal) to encourage them to switch to another supplier. The distribution of responses is shown in Table 3 . The data for the value question were coded at the midpoint of the intervals in Table 3 except for 'More than \$20' which was coded as 25 . We therefore estimated a Tobit model allowing for both left and right hand censoring (at 2 and 25). The Tobit model specification is: $y^{\square}=\mathbf{x}^{\prime} \beta+\varepsilon$ where $\varepsilon$ is a continuous random variable with mean zero and variance $\sigma^{2}$. $y_{i}^{*}$ yi

$\square$ is a latent variable with

$$
y_{i}^{*}=\left\{\begin{array}{l}
y_{i}^{*} \text { if } \quad a<y_{i}^{*}<b \\
a \text { if } \quad y_{i}^{*} \leq a \\
b \text { if } y_{i}^{*} \geq b
\end{array}\right.
$$

Table 3. Savings required to switch providers.

D5. If another company offered exactly the same services and quality as your current electricity provider, how much would your electricity bill have to decrease each month to encourage you to switch to the other company (Please circle one)

\begin{tabular}{llllllll}
\hline & $\$ 0-\$ 4$ & $\$ 5-\$ 9$ & $\$ 10-\$ 14$ & $\$ 15-\$ 20$ & $>\$ 20$ & Do not know & Average savings \\
\hline Watauga (\%) & 3 & 8 & 20 & 21 & 29 & 19 & $\$ 17.04$ \\
Forsyth (\%) & 4 & 10 & 24 & 22 & 26 & 16 & $\$ 16.22$
\end{tabular}

The expected value of the dependent variable is

$$
\begin{aligned}
E[y \mid x]= & a \operatorname{Prob}\left[y_{\leq}^{* *} a \mid x\right]+b \operatorname{Prob}\left[y^{*} \geq b \mid x\right] \\
& +\operatorname{Prob}\left[a<y^{*}<b \mid x\right] E\left[y^{*} \mid a<y^{*}<b\right]
\end{aligned}
$$

where $a$ and $b$ are constants taking on values of 2 and 25, respectively, in our model.

As a check on the sign and significance of the results, we also estimated an ordered logit model where the dependent variable is the ordinal value of responses; e.g., 0-4 was coded as 1, etc. The 'don't know' responses were excluded. These results are shown in Table 4. 
Table 4. Tobit models with marginal effects. Ordered logit with robust standard errors. $y=s a v i n g s$. $p$-values are in parentheses.

\begin{tabular}{llll} 
Variable & Model 1 (Tobit) & Model 2 (Tobit) & Model 3 (ologit) \\
\hline Predicted value & Switch=15.25 & Switch=15.30 & \\
County & .6406 & .5281 & .2594 \\
& $(0.058)$ & $(0.122)$ & $(0.134)$ \\
Income & .0000161 & .0000159 & .00000751 \\
& $(0.007)$ & $(0.008)$ & $(0.006)$ \\
Age & -.0242 & -.0240 & -.0106 \\
& $(0.048)$ & $(0.052)$ & $(0.075)$ \\
Male & -.0432 & .0590 & .0209 \\
& $(0.901)$ & $(0.866)$ & $(0.901)$ \\
Race & -1.5203 & -1.6114 & -.7422 \\
& $(0.041)$ & $(0.029)$ & $(0.063)$ \\
College & -1.4702 & -1.4917 & -7123 \\
& $(0.002)$ & $(0.002)$ & $(0.002)$ \\
Professional & -2.2110 & -2.1868 & -1.0201 \\
& $(0.000)$ & $(000)$ & $(0.000)$ \\
Favor & & -.7339 & -.3334 \\
& & $(0.038)$ & $(0.075)$ \\
Priorswitch & & -6691 & -.3237 \\
& & $(0.062)$ & $(0.063)$ \\
$N$ & 507 & 504 & 504 \\
Left censored & 22 & 22 & \\
Right Censored & 165 & 165 &
\end{tabular}

Model 1 does not control for respondents' prior experience switching providers in other industries (priorswitch) or whether they favor competition (favor). These controls are added in models two and three. The results for the demographic variables do not change substantially when these two variables are included.

Respondents with a college education require less savings to switch suppliers than those with a high school education, and adding professional/post-graduate education lowers the savings more. Of course, education is correlated with income which is also significant but positive. $\stackrel{11}{.}$ Age and race are negative and significant meaning older respondents require less savings to switch and whites require less than non-whites. $\frac{12}{}$ Being favorable towards competition and having experience switching in other industries reduces respondents required savings also.

To determine characteristics that make respondents more favorable toward competition we estimated a logit model with the form

$$
\begin{aligned}
\text { p(favor }=\text { yes } \mid x)=\frac{1}{1+e^{-\beta^{\prime} x}} \\
\text { where } \begin{aligned}
\beta^{\prime} \mathrm{x}= & \beta_{0}+\beta_{1} \text { county }+\beta_{2} \text { income } \\
& +\beta_{3} \text { age }+\beta_{4} \text { male }+\beta_{5} \text { race }+\beta_{6} \text { college } \\
& +\beta_{7} \text { professional }+\beta_{8} \text { priorswitch }
\end{aligned}
\end{aligned}
$$

These results are shown in Table 5. 
Table 5. Logit model, $y=$ favor retail competition ( $p$-values).

\begin{tabular}{ll}
$\mathrm{n}=612$ & Prob $>\mathrm{chi}^{2}=.0001$ \\
\hline Constant & -20.019 \\
& $(.108)$ \\
County & -.2056 \\
& $(.245)$ \\
Income & .00000137 \\
& $(.659)$ \\
Age & .0101 \\
& $(.113)$ \\
Male & .3375 \\
& $(.061)$ \\
Race & -.0091 \\
& $(.984)$ \\
College & .4649 \\
& $(.047)$ \\
Professional & .4711 \\
& $(.090)$ \\
Priorswitch & .6607 \\
& $(.001)$
\end{tabular}

Respondents with either a college education or a professional degree are both more favorable towards competition than those with a high school education but the coefficient on the professional degree is only significant at the $10 \%$ level. Males are also somewhat more likely to favor competition than females. Lastly having experience switching in other industries increases the probability of favoring competition between electricity providers suggesting that individuals who have switched either their telephone or television suppliers find these choices beneficial and would like to have them available in the electrical market.

\section{Discussion}

Fig. 2 and Table 6 show that North Carolina has residential electricity rates below the national average; Table 6 shows the rates for the four providers in our survey areas.

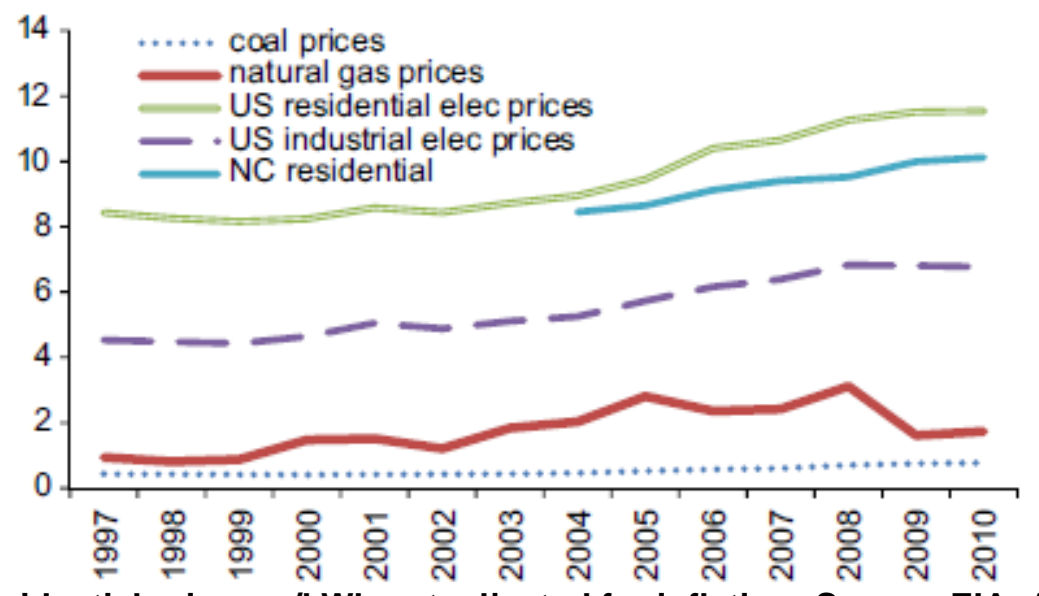

Fig. 2. Fuel and residential prices. $\$ / \mathrm{kWh}$ not adjusted for inflation. Source: EIA. Average Retail Price of Electricity to Ultimate Customers: Total by End-Use Sector, 1997 through December 2011, Short term energy outlook (March 6, 2012). Power generation fuel costs; \$/million BTU converted to cents/kWh using 1 million BTU=293.071 kWh. 
Table 6. Rates and ownership for the electricity companies in our survey area.

Source: ElA. Electricity Sales, Revenue, Average Price 2008 (Tables 6 and 5a).

\begin{tabular}{llrr}
\hline Utility & Ownership & Average residential rate (cents/kWh) & Number of NC Customers \\
\hline Blue Ridge Electric & Cooperative & 11.01 & 61,640 \\
New River Light and Power Company & Public (University owned) & 8.12 & 5840 \\
Duke & Investor owned & 8.22 & $1,563,543$ \\
EnergyUnited & Cooperative & 10.33 & 104,083 \\
NC & & 9.52 & \\
US & & 11.26 &
\end{tabular}

New River Light and Power Company is owned by Appalachian State University and has a very small, dense customer base in downtown Boone, North Carolina. Blue Ridge Electric services other areas of Boone and the remainder of Watauga County. Duke Energy supplies most of the customers in Forsyth County; a few are served by Energy United.

Based on model 2 the probability of 'savings' being uncensored and the conditional predicted value of 'savings' are

$$
\begin{aligned}
& P(2 \leq \text { savings } \leq 25)=.6931 \\
& E(\text { savings } 2 \leq \text { savings } \leq 25)=15.30
\end{aligned}
$$

The conditional (censored) reduction on the electricity bill that would incent customers to switch suppliers is $\$ 15.30 /$ month across the two counties (all else equal). To compute a rough estimate of the equivalent reduction in tariff rates we use summary data for NC as a whole. The average monthly residential consumption in NC for 2008 was $1120 \mathrm{kWh}$; the average bill was $\$ 106.61$ and the average price was $9.52 \$ / \mathrm{kWh}$. A reduction in the monthly bill of $\$ 15.30$ would be a reduction of approximately $14.35 \%$ a month or $1.37 \Phi / \mathrm{kWh}$.

Determining if this is a realistic rate reduction is problematic, but we can look to the experience of the US states that have introduced retail competition. As discussed in Kwoka (2008) some states introduced competition as early as 1996 and rates were initially capped to allow utilities to recover stranded costs. Rate caps made market entry unattractive and the impact of competition on retail prices could not therefore be accurately determined. In many cases those caps have now expired, however. Swadley and Yücel (2011) use a dynamic panel analysis including 16 US states plus the District of Columbia to analyze factors contributing to price changes following the introduction of competition. Their sample period spans 1990-2010. In their model consumer switching/participation is a significant determinant of residential rates, but with a lag. They find that increasing participation by $10 \%$ lowers the residential price by $4.3 \% 6$ months later. State specific restructuring plans are important in their results as is the marginal generation fuel. They explain that Maine provides a 'standard offer service' that procures generation competitively. As such, many consumers are part of the competitive market (and pay lower rates) though they are not active switchers. This is akin to the Basic Electricity Service (BES) Joskow (2000) favors. He argues a BES 
"option provided by the [electric distribution companies] that allows retail customers to buy directly from the wholesale market should be the benchmark against which the social benefits of retail competition and the best mechanisms to realize these benefits should be judged...successful retail competition should provide value-added services to customers over and above what they can realize through direct access to the wholesale market" (p. 4). In Joskow's view the fact that consumer switching is low is not an indication of competitive market failure. The incentives and scope to provide value added services indicate how successful the competitive transition is or will be.

In Swadley and Yücel's model both coal and natural gas affect residential rates (with a lag), and where natural gas is marginal (e.g., Texas, California, New York and New England), fuel prices affect rates significantly more when the market is competitive; competition does not change the effect of fuel prices on rates when coal is marginal, however. Fig. 2 shows nominal coal and natural gas prices between 1997 and 2010 and illustrates that coal prices have been steadier than natural gas prices. The figure also shows the gap between retail and industrial prices in the US. Industrial prices tend to be close to wholesale price, particularly where there is competition.

Fig. 3 shows that NC is heavily dependent on coal and nuclear for electricity production and uses little natural gas. Swadley and Yücel (2011, Table 2) show the generation mix for the deregulated states included in their study. Of those states, NC's generation mix is similar to Illinois, Maryland, Michigan, Pennsylvania and Virginia (which has suspended its deregulation efforts). Swadley and Yücel note that retail competition has been less successful to date in coal intensive states (with exceptions, notably Pennsylvania). They show that retail prices fell in Pennsylvania after the market became competitive but note that not all price controls had expired over their period of analysis. Of the other coal intensive states that are currently competitive (Illinois, Maryland and Michigan) they instead find that retail prices increased following deregulation. The participation rate (i.e., the percentage of consumers taking competitive supply) in these states was very low over their sample period.

Fig. 3. Generation mix for NC and the US. Source: EIA, Electric Power Annual. Net Generation total electric power industry by energy source, 2010.

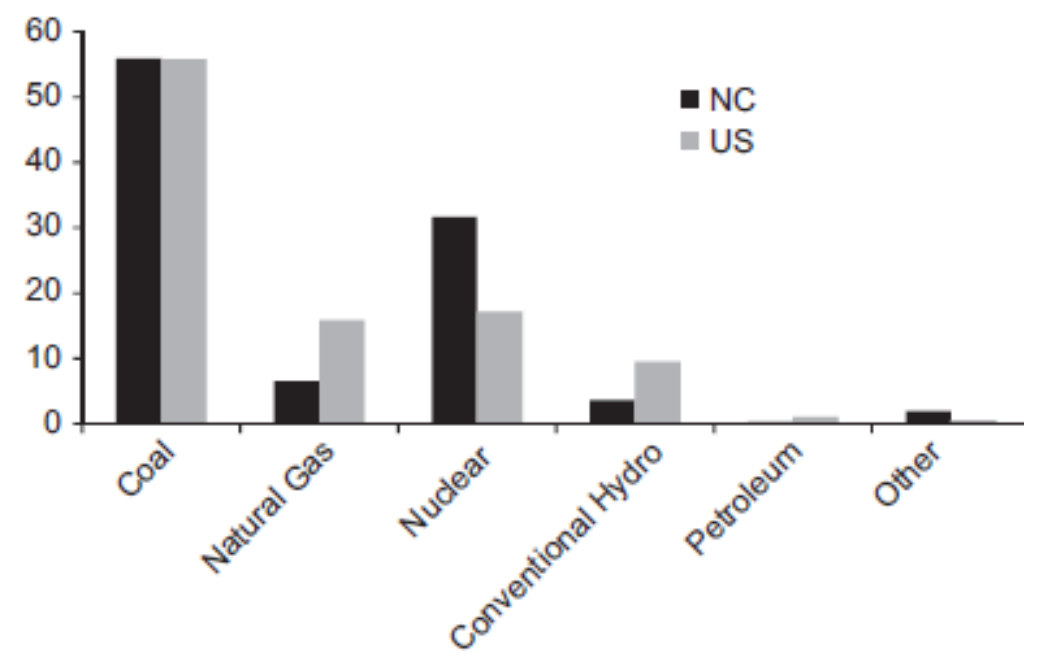


In Texas, where retail competition began in 2002 and has largely been viewed as a success, price caps expired in 2007. Kang and Zarnikau (2009) show evidence that prices have since begun to fall. The electricity industry in Texas is heavily reliant on natural gas, so electricity prices rose steadily along with natural gas prices in 2004 and 2005. According to Kang and Zarnikau, electricity prices remained high even when natural gas prices began declining in 2006 (Fig. 1, p. 1715). Zarnikau and Whitworth (2006) discuss that most residential customers have chosen to remain on a (regulated) price-to-beat contract as opposed to switching to a competitive supplier. These price-tobeat tariffs are not the same as the BES Joskow (2000) proposes and were initially offered at a discount that left little margin for potential competitors.

A state's experience with retail competition will depend on its policy towards stranded cost recovery, strategies for providing default services to customers who choose not to switch suppliers, the current generation mix, consumers' attitudes and the scope for suppliers to innovate. North Carolina's access to cheap coal has kept prices below the national average, but prices could increase as the state's commitment to greener technologies strengthens. In $2007 \mathrm{NC}$ implemented a renewable energy and efficiency portfolio standard requiring "investor-owned utilities to supply $12.5 \%$ of their electricity from renewable and efficiency sources by 2021 , and municipal electric suppliers and rural electric cooperatives to supply $10 \%$ by $2018 . " \underline{16}$ Higher tariffs from increased reliance on renewables could encourage innovation, and the support for competition could improve despite higher rates. The use of smart meters could bring down competitors' costs, but not necessarily below the incumbents' (some of which have already rolled out smart meters).

\section{Conclusion}

We conducted a mail survey of two disparate counties in western North Carolina to gage consumers' opinions about retail competition among electricity providers and to estimate their required savings to switch providers. Just under half of our respondents claimed to know something about electricity retail competition; about $75 \%$ of responders in each county believe it is important that consumers be able to choose their utility provider, and $50-65 \%$ favor retail competition in NC. Our results show that respondents with undergraduate and post-graduate education are more likely to favor competition than those without college experience, and males are somewhat more likely to favor competition than females. Respondents who have recently switched television or phone providers are more likely to favor competition, and they would require less savings to switch than those who have not recently switched providers in these other industries. On average households state they would be willing to switch electricity providers (all else equal) for a rate reduction of approximately $1.4 \$ / \mathrm{kWh}$. There were no strong differences between the two counties.

Given that prices in NC are still regulated and below the national average, savings of this magnitude are currently unlikely; evidence from other states suggests alternative suppliers would be unable to compete at such rates. So the answer to the question: "Should NC reconsider retail competition?" Our survey of residential consumers suggests that from a purely consumer welfare perspective the answer is no. If, however, 
retail competition encourages cost savings on the production side, or if it is implemented only for industrial and commercial consumers, then the answer might be yes but is beyond the scope of our analysis.

In the future we would like to conduct a larger study of the southeastern US to form a better picture of consumer preferences in this part of the country where electricity has been historically cheap due largely to the dominance of coal (and some nuclear) in the generation mix. In addition we plan to study demand side management by asking if consumers are willing to use smart grid technologies with time varying pricing as well as conservation measures to reduce energy use. 


\section{References}

Blumstein, C., Friedman, L., Green, R., 2002. The history of electricity restructuring in California. Journal of Industry, Competition and Trade 2 (1/2), 9-38.

Cramton, P., 2003. Electricity market design: the good, the bad, and the ugly. In: Proceedings of the Hawaii International Conference on System Sciences.

Defeuilley, C., 2009a. Retail competition in electricity markets. Energy Policy 37, 377-386.

Defeuilley, C.,2009b.Retail competition in electricity markets-expectations and outcomes: a reply. Energy Policy37,764-765.

Faruqui, A.,Sergici,S.,2010.Household response to dynamic pricing of electricity: a survey of 15 experiments .Journal of Regulatory Economics38,193-225.

Greene, W.,2002. Econometric Analysis, fifth ed. Princeton Hall.

Joskow, P.,2000. Why do we need electricity retailers? Or can you get cheaper wholesale? Working Paper, Center for Energy and Environmental Policy Research, MIT.

Joskow, P, Tirole.,J.,2006.RetailElectricityCompetition.TheRandJournalof Economics 37(4),799-815.

Kang, L., Zarnikau,J.,2009.Did the expiration of retail price caps affect prices in the restructured Texas electricity market? Energy Policy,1713-1717.

Kwoka, J., 2008. Restructuring the U.S. electric power sector: a review of recent studies. Review of Industrial Organization 32,165-196.

Littlechild, S.,2008. Municipal aggregation and retail competition in the Ohio energy sector. Journal of Regulatory Economics34,164-194.

Littlechild, S.,2009. Retail competition in electricity markets-expectations, out- comes and economics. EnergyPolicy37,759-763.

Nakajima, T.,Hamori,S.,2010.Change in consumer sensitivity to electricity prices in response to retail deregulation: a panel empirical analysis of the residential demand for electricity in the United States. Energy Policy 38 2479-2476.

Sidak, J.,Spulber,D.,1998. Deregulatory Takings and the Regulatory Contract. Cambridge University Press.

Swadley, A.,Y“" ucel, M.,2011.Did residential electricity rates fall after retail competition? A dynamic panel analysis. Energy Policy39,7702-7711.

U.S.A Department of Energy, Energy Information Association. /http://www.eia. doe.gov/S. 
Whitehead, J.,Groothuis,P.,Blomquist,G.,1993.Testing for non-response and sample selection bias in contingent valuation: analysis of a combination phone/mail survey.EconomicsLetters41,215-220.

Zarnikau, J.,Whitworth,D.,2006. Has electric utility restructuring led to lower electricity prices for residential customers in Texas? Energy Policy34,2191-2200. 